BMJ Open Sport \& Exercise Medicine

\title{
Lean and mean? Associations of level of performance, chronic injuries and BMI in sport climbing
}

\author{
Gudmund Grønhaug
}

To cite: Grønhaug G. Lean and mean? Associations of level of performance, chronic injuries and BMI in sport climbing. BMJ Open Sport \& Exercise Medicine 2019;5:e000437. doi:10.1136/ bmjsem-2018-000437

Accepted 12 November 2018

Check for updates

(c) Author(s) (or their employer(s)) 2019. Re-use permitted under CC BY-NC. No commercial re-use. See rights and permissions. Published by BMJ

Department of Physical Medicine and Rehabilitation, Østfold Hospital Trust, Grålum, Norway

Correspondence to Gudmund Grønhaug; gudmund. gronhaug@so-hf.no

\section{ABSTRACT}

Objectives To assess possible associations between performance level (achieved level of difficulty), chronic injuries and body mass index (BMI) in sport climbing.

Method Retrospective survey.

Setting Web-based questionnaire.

Participants 667 active climbers (385 reported having chronic injuries).

Outcome measure BMI, performance level in sport climbing, onset of a climbing-related injury, preferred style of climbing, education, gender.

Statistics Descriptive statistics and general linear model(GLM) performed with SPSS V.25 for windows. Result No associations were found between level of performance in sport climbing, onset of a climbing-related injury, preferred style of climbing, education, gender and BMI.

Conclusion BMI is not associated with climbing-related chronic injury or level of performance in climbing. The average BMI of climbers up to the elite level is similar to that of a lower rate of performance.

Clinical relevance The findings in this study suggest that there is no need for maintaining a low BMI to be able to reach elite levels in climbing.

All sports, new or old, require their own specific sets of skills. Some sports are even said to require specific genes to enable the athlete reach the international elite level. ${ }^{1}$ Sport climbing is a relatively young sport that has been growing rapidly in the past decade. In sports, comparable to climbing in terms of criteria for success and anthropometrics like gymnastics running and ski jumping, the body mass index (BMI) is linked to performance $^{23}$ and injuries. ${ }^{4}$ During a climbing performance the load on the fingers, elbow and shoulders is shown to be substantial. ${ }^{5}$ Furthermore, the physiological load increases with an increase in BMI; a lower BMI will give a lower load and thereby, apparently, reduce the odds for injury.

The literature on physiological demands in climbing and the risks for injury is growing. ${ }^{6-11}$ However, studies reporting BMI and risk for injuries in climbing do not distinguish between acute and chronic injuries. In most sports the onset of an injury differs for

\section{What was known}

Low body mass index (BMI) increases the strengthto-weight ratio.

- High BMI increases the load on muscles and joints when climbing.

- It has been suggested that higher BMI increases the risk for certain types of injuries.

\section{What is new}

- There are no associations between climbing related chronic - injury, level of performance and BMI.

- BMI is not a predictor for reaching elite levels in climbing.

- There are no big differences in BMI between male and female climbers in any level of performance.

- The body appears to adapt to the load regardless of a high or low BMI.

acute and chronic injuries. An acute injury in climbing is often a high energy trauma entailing an obvious reason to seek medical aid. Thereby it differs from the onset of chronic injuries. Research on climbing injuries reveals that chronic injuries are more prevalent than acute injuries. ${ }^{812}$ Still, research on chronic injuries in climbing has for the most part been focusing on single diagnosis or using only a few subjects for assessments. ${ }^{13}$

The purpose of this study is to investigate possible associations between performance level (achieved level of difficulty), chronic injuries and BMI

\section{METHODS}

\section{Design}

This study is based on a cross-sectional survey using a web-based questionnaire. The respondents were asked to reply to the questionnaire based on experiences with chronic injuries and not acute injuries. No further definition or operationalization of chronic injuries was given.

The national climbing federation helped promote the survey via their web pages. It was 
Table 1 Grouping of level of performance in climbing with comparable levels for route climbing and bouldering using the French grades of difficulty for routes and bouldering

\begin{tabular}{lll}
\hline & Route climbing & Bouldering \\
\hline Recreational & $4-6 \mathrm{~b}$ & $4-5+$ \\
Intermediate & $6 \mathrm{~b}+-7 \mathrm{a}+$ & $6 \mathrm{~A}-6 \mathrm{C}+$ \\
Experienced & $7 \mathrm{~b}-8 \mathrm{~b}$ & $7 \mathrm{~A}-7 \mathrm{C}$ \\
Elite & $8 \mathrm{~b}+-8 \mathrm{c}+$ & $7 \mathrm{C}+-8 \mathrm{~A}+$ \\
International elite & $9 \mathrm{a}->$ & $8 \mathrm{~B}->$ \\
\hline
\end{tabular}

also promoted by the national climbing magazine and was published on Facebook pages and web pages during the time of inclusion. The questionnaire was open for respondents from 21 March 2017 to 02 May 2017.

The questionnaire contained questions on:

Sociodemographics and experience level.

The questionnaire included questions about gender, height and weight.

To assess level of experience questions were asked about the highest achieved grade during the last 6 months for a prepracticed climb (Red point). Experience levels were grouped as suggested in Grønhaug and Norberg $2016^{7}$ (table 1). The table also makes it possible to group the climbers regardless of whether the highest level is achieved in bouldering or route climbing.

\section{Total amount of training}

Furthermore questions were asked about what kind of climbing the respondents preferred (bouldering, route, trad, multipitch, ice or 'not sure'). A question on total amount of weekly training was answered with ' $>1,1-3$, $4-7,8-10,<11$ '. The question 'do you train any other than climbing' was a 'yes/no' question.

\section{Self-perceived injuries}

During the past 6 months, have you experienced climbing-related chronic injuries? (yes, no).

\section{Statistics}

SPSS V.25 for Mac was used. Descriptive analyses were performed to assess the characteristics of the respondents. Results from the descriptive analyses are presented as means $\pm \mathrm{SD}$ where applicable. Assessment of factors associated with BMI was done with univariable regression analysis (general linear model-GLM). Level of significance is set to $95 \%$. Results from the univariable tests are presented with $\beta, 95 \% \mathrm{CI}, \mathrm{p}$ values and $\mathrm{R}^{2}$.

\section{RESULTS}

\section{Participant characteristics}

Most of the respondents were male $(72.1 \%), 58.7 \%$ were 26-40 years of age (28.3\% 26-30 years and $30.4 \%$ 31-40 years) and had been climbing for at least 3 years (3-5 years $30.1 \%$, $6-10$ years $22.3 \%, 11+$ years $29.1 \%$, respectively) (table 2).
Table 2 Respondent characteristics including mean body mass index (BMI) for each subgroup. BMI presented as mean \pm SD

\begin{tabular}{|c|c|c|}
\hline Variable & $\mathbf{n}=$ & Mean BMI (SD) \\
\hline \multicolumn{3}{|l|}{ Gender } \\
\hline Male & 481 & $22.81(2.30)$ \\
\hline Female & 186 & $22.71(2.21)$ \\
\hline BMI (mean) & \multicolumn{2}{|c|}{22.78} \\
\hline \multicolumn{3}{|l|}{ Education } \\
\hline Primary school & 10 & $22.71(2.13)$ \\
\hline Secondary school & 55 & $23.28(2.36)$ \\
\hline Certificate of apprenticeship & 50 & $22.85(2.45)$ \\
\hline University 3 years & 199 & $22.83(2.25)$ \\
\hline University 5 years & 226 & $22.74(2.36)$ \\
\hline $\mathrm{PhD}$ & 115 & $22.48(2)$ \\
\hline Other & 12 & $22.84(2.75)$ \\
\hline \multicolumn{3}{|l|}{ Total hours of training weekly } \\
\hline$<1$ & 4 & $22.83(1)$ \\
\hline $1-3$ & 65 & $23.19(2.2)$ \\
\hline $4-7$ & 267 & $22.73(2.41)$ \\
\hline $8-10$ & 233 & $22.74(2.08)$ \\
\hline$>11$ & 98 & $22.73(2.39)$ \\
\hline \multicolumn{3}{|c|}{ Highest level of climbing past 6 months } \\
\hline Recreational (4-6b) & 137 & $22.87(2.25)$ \\
\hline Intermediate $(6 b+-7 a+)$ & 342 & $22.73(2.25)$ \\
\hline Experienced (7b-8b) & 170 & $22.78(2.35)$ \\
\hline Elite $(8 b+-8 c+)$ & 17 & $23.04(1.95)$ \\
\hline International elite $(9 a->)$ & 1 & $19.29\left(\mathrm{NA}^{*}\right)$ \\
\hline \multicolumn{3}{|c|}{ Are you doing any other training than climbing } \\
\hline Yes & 559 & $22.82(2.26)$ \\
\hline No & 108 & $22.56(2.29)$ \\
\hline
\end{tabular}

Have you experienced an injury in the past 6 months

\begin{tabular}{lrl} 
Yes & 385 & $22.74(2.2)$ \\
\hline No & 282 & $22.84(2.37)$ \\
\hline Where did you have an injury & & \\
\hline Toe & 1 & $22.41(\mathrm{NA})$ \\
\hline Foot/ankle & 21 & $22.12(1.58)$ \\
\hline Calf & 2 & $24.66(0.95)$ \\
Knee & 15 & $22.55(1.49)$ \\
\hline Thigh & 3 & $22.7(4.48)$ \\
\hline Hip & 3 & $23.59(2.01)$ \\
\hline Lower back & 11 & $22.49(3.15)$ \\
\hline Shoulder & 75 & $22.93(2.64)$ \\
\hline Elbow & 68 & $23.2(2.07)$ \\
\hline Wrist & 24 & $22.39(2.32)$ \\
\hline Fingers & 159 & $22.6(2.01)$ \\
\hline Neck & 2 & $21.04(2.02)$ \\
\hline
\end{tabular}

Continued 


\begin{tabular}{lrl} 
Table 2 Continued & & \\
\hline Variable & $\mathbf{n}=$ & Mean BMI (SD) \\
\hline \multicolumn{1}{c}{ Head } & 1 & $23.3\left(\mathrm{NA}^{*}\right)$ \\
Preferred style of climbing & & \\
Bouldering & 196 & $22.81(2.34)$ \\
Rope & 169 & $22.81(2.24)$ \\
Trad & 195 & $22.55(2.24)$ \\
Multipitch & 44 & $22.72(2.23)$ \\
Ice & 59 & $23.34(2.18)$ \\
Not sure & 4 & $23.06(2.37)$ \\
\hline
\end{tabular}

${ }^{*} \mathrm{NA}$, not applicable due to low $\mathrm{n}$.

Of the respondents $49 \%$ was intermediate $(6 \mathrm{~b}+-7 \mathrm{a}+)$ and $34 \%$ was experienced ( $7 \mathrm{~b}-8 \mathrm{~b})$. The experience level was higher among the men than women with $36.3 \%$ experienced men and $27.4 \%$ experienced women. There were $3.5 \%$ elite and $0.2 \%$ international elite climbers among all the respondents. Chronic injuries was reported by $58 \%$ of the respondents.

Further results are presented in table 3 .

\section{DISCUSSION}

The findings in this study indicate that there are no associations between level of climbing, chronic injuriesor training volume and BMI. It is also found that the average BMI is similar across groups regardless of genderand level of performance.

In the climbing community it has been a well-established 'truth' that a low BMI is preferable to be climbing on a high level. The nature of climbing, where you progress up a wall using nothing but hands and feet, makes it plausible that it is a sport that relies heavily on strengthto-weight ratio.

When climbing, the workload is high on fingers, elbows and shoulders. Furthermore, as a climber relies only on relative strength (power-to-weight ratio) to progress up a wall, it is easy to understand the assumption that there is less strain on the fingers, elbows and shoulders for a light climber than a heavy climber. Although this assumption seems intuitive, it is wrong; a light climber and a heavy climber are both training with their own body weight. Tendons, muscles and other structures in the body are adapting accordingly to the stress they are given; a light climber applies less stress to the tendons and muscles than a heavy climber and the tendons and muscles are developed accordingly, resulting in the same adaption in the strength-to-weight ratio. This may explain the finding in the present study that there are no associations between higher BMI and rate of injuries. This finding is in line with previous studies on chronic injuries in climbing. ${ }^{7}$ But this is in contrast with the findings of Lion et al. ${ }^{5}$ Lion et al suggest that there is an association between finger injuries and BMI. There are several methodological differences between these two studies, the most important one might be the time frame of the retrospective study (3 years recall in Lion et al and 6 months in the previous). Another difference is the level of performance and the grouping of the respondents. In Lion et al the beginners (performance level of French grade $6 a+$ and less) are the reference group. As seen in previous studies, grouping climbers in terms of performance in the previous year, this group is likely to have sustained few climbing-related finger injuries compared with the other climbers. ${ }^{12-14}$ Finger injuries are more common in the higher levels of performance. ${ }^{814}$ In the present study the climbers have a wider range of performance level and, as seen in tables 2 and 3, the average BMI is almost identical for all levels of performance and has no associations with injuries.

BMI may have a positive impact on short-term goals and reducing weight prior to a competition or a climbing trip may give short-term benefits. ${ }^{15-17}$ This effect may however be undermined by fatigue or injuries due to malnutrition as keeping a low BMI over time impacts general overall health and increases risk of overuse injuries. ${ }^{9} 18$ Malnutrition in athletes, and especially in those who are either doing body weight sports or endurance athletics, is suggested to be underassessed. ${ }^{19}$ A low BMI may be an indicator for malnutrition. As proper diet is needed for recovery after exercise-induced physiological stress, recovery may be poorer in athletes with low BMI. ${ }^{20}$ Athletes with longer periods of malnutrition, either due to competitions or fear of losing power, may be at risk for underperformance and even alterations of the immune system. ${ }^{21}$ Low BMI is associated with lower bone mineral density, even in runners. ${ }^{22}$ As climbers undergo less weight-bearing training than runners, the climber with a low BMI may be at greater risk for low bone mineral density (BMD) than the runners studied. For young athletes the impact of low BMI and thereby lowBMD combined with high levels of training may give rise to an increase in bone deformities and epiphysial stress fractures. ${ }^{2324}$ In the long term the overall fitness and ability to train hard over longer periods of time is probably of higher importance than keeping a low BMI over time.

\section{STRENGTHS AND LIMITATIONS}

This study is a cross-sectional open on-line survey on chronic injuries during climbing. It may be that some respondents have been reluctant to take part in an online survey. It is likely that the climbers responding to the survey used in this study are more prone to have sustained an injury than the average climber. Still, almost $42 \%$ of the respondents reported that they had no injury in the last 6 months.

The time of the survey may have had an impact on the reported injuries. Since the survey was open from 21 March 2017 to 02 May 2017, most of the climbers may have been climbing indoors more than usual due to the cold weather. Since the seasonal and the outdoor climbers often use indoor climbing in winter as a period of harder training than usual, this may have had an impact on injury rates during the last 6 months. 
Table 3 GLM analysis assessment of possible associations of body mass index (BMI) and the variables included in the study. presented with $\beta$ (intervariable difference in BMI Score), Cls with $p$ values, and partial $R^{2}$ (the variables portion of explaining scores on $\mathrm{BMI})$

\begin{tabular}{|c|c|c|c|c|c|}
\hline & & $\beta$ & $95 \% \mathrm{Cl}^{*}$ & $\mathbf{P}$ & $\mathbf{R}^{2}$ \\
\hline \multirow[t]{3}{*}{ Gender } & & & & , 155 & ,004 \\
\hline & Male & Reference & & & \\
\hline & Female & ,336 & -,128 - 801 & 155 & ,004 \\
\hline \multirow[t]{7}{*}{ Education } & & & & ,703 & ,006 \\
\hline & Primary school & ,095 & $-1,273-1,462$ & ,892 &, 000 \\
\hline & Secondary school & ,046 & $-1,456-1,548$ & ,952 & ,000 \\
\hline & $\begin{array}{l}\text { Certificate of } \\
\text { apprenticeship/Other }\end{array}$ & ,613 & $-, 087-1,313$ & ,086 & ,005 \\
\hline & University 3 years & ,120 &,$- 610-, 849$ & ,747 & ,000 \\
\hline & University 5 years & ,097 &,$- 353-, 546$ & ,672 & ,000 \\
\hline & $\mathrm{PhD}$ & Reference & & & \\
\hline \multirow[t]{7}{*}{$\begin{array}{l}\text { Total hours of weekly training last } 6 \\
\text { months }\end{array}$} & & & & ,541 & ,008 \\
\hline & Not been training &,- 607 & $-1,837-, 622$ & ,333 & ,002 \\
\hline & $<1$ hour & $-1,134$ & $-3,938-1,671$ & ,428 & ,001 \\
\hline & $1-3$ hours & ,690 & $-, 320-1,699$ & 180 & ,003 \\
\hline & 4-7 hours & ,030 &,$- 614-, 674$ & ,927 &, 000 \\
\hline & $8-10$ hours & ,039 &,$- 591-, 670$ & ,902 & ,000 \\
\hline & $>11$ hours & Reference & & & \\
\hline \multirow[t]{5}{*}{ Highest level of climbing past 6 months } & & & & 840 & ,002 \\
\hline & Recreational &,- 216 & $-1,517-1,085$ & ,745 &, 000 \\
\hline & Intermediate &,- 368 & $-1,598-, 863$ &, 558 & ,001 \\
\hline & Experienced &,- 434 & $-1,684-, 815$ & ,495 & ,001 \\
\hline & Elite/International elite & Reference & & & \\
\hline \multirow[t]{3}{*}{$\begin{array}{l}\text { Are you doing any other training than } \\
\text { climbing }\end{array}$} & & & & 631 & ,000 \\
\hline & Yes &,- 252 & $-1,283-, 779$ & ,631 &, 000 \\
\hline & No & Reference & & & \\
\hline \multirow[t]{3}{*}{$\begin{array}{l}\text { Have you experienced an injury past } 6 \\
\text { months }\end{array}$} & & & & 447 & ,001 \\
\hline & Yes &,- 156 &,$- 560-, 247$ &, 447 &, 001 \\
\hline & No/not sure & Reference & & & \\
\hline
\end{tabular}

${ }^{*} 95 \% \mathrm{Cl}$ presented with lower bound, upper bound.

A weakness of the study is the lack of medical examination of the reported injuries. Although the questionnaire specified that the study was about chronic injuries, it is not guaranteed that the respondents only reported chronic injuries; some may have reported acute injuries.

Another weakness of the study is the use of cross-sectional data to assess associations of BMI and rate of injury and performance. Using cross-sectional data to predict a long-term effect is unreliable and the results should be interpreted carefully.

The lack of medical examination, the absence of a proper definition of what is an acute injury and what is to be considered a chronic injury, in the survey, is a weakness of the study.

A strength of the study is the number of participants, the wide range of experience among the respondents and the high number of female respondents. The generalisability of a study relies on the participants. Two groups are underrepresented in this study; the beginners and the international elite. Beginners often quit climbing or do not climb regularly, and will probably be less injured than the other groups, but will probably have the same average BMI as the others, making the result more skewed. The underrepresentation of the international 
elite is problematic in terms of the robustness of the finding that BMI does not predict performance level. This needs further investigation. Apart from these two groups the composition of the respondents in this study is in line with the climbing community in Norway.

Sorting the respondents by level of experience is a strength of the study that makes it more generalisable.

Another strength of the study is that it is a national survey and is not limited to a city or just a few climbing gyms. Due to support from the national federation and the national climbing media, this survey has respondents from all over Norway; this gives the study a higher level of generalisability. Furthermore, it is a study with the highest number of climbers participating so far.

Another strength of the study is that a high proportion of the participants did not report an injury. With $58 \%$ of the climbers reporting an injury, the numbers are probably still slightly higher than they would be in a prospective study. This is probably due to a selection bias making those who have sustained an injury far more likely to reply to a study on chronic injuries than those who have never experienced a chronic injury.

\section{CONCLUSION}

BMI is not associated with chronic injury or level of performance in climbing. The average BMI of climbers up to the elite level is similar to those having a lower performance level.

\section{Clinical relevance}

The findings in this study suggest that there is no need for a low BMI to be able to reach elite levels in climbing. This should be taken seriously by the national federations, magazines on climbing and bloggers to avoid unnecessary weight control by climbers wanting to reach higher levels of performance.

Acknowledgements The author thanks Marius Norberg for contribution towards development of the questionnaire.

Collaborators Marius Norberg.

Contributors I'm the sole author of this manuscript.

Funding The authors have not declared a specific grant for this research from any funding agency in the public, commercial or not-for-profit sectors.

\section{Competing interests None declared.}

Patient consent for publication Not required.

Ethics approval The survey is approved by the regional ethics committee. Ref $\mathrm{nr}$ 2016/1533.

Provenance and peer review Not commissioned; externally peer reviewed.

Open access This is an open access article distributed in accordance with the Creative Commons Attribution Non Commercial (CC BY-NC 4.0) license, which permits others to distribute, remix, adapt, build upon this work non-commercially, and license their derivative works on different terms, provided the original work is properly cited, appropriate credit is given, any changes made indicated, and the use is non-commercial. See: http://creativecommons.org/licenses/by-nc/4.0/

\section{REFERENCES}

1. Norton K, Olds T. Morphological evolution of athletes over the 20th century: causes and consequences. Sports Med 2001;31:763-83.

2. Bacciotti S, Baxter-Jones A, Gaya A, et al. The physique of elite female artistic gymnasts: a systematic review. J Hum Kinet 2017;58:247-59.

3. Janura M, Elfmark M, Cabell L, et al. Ski-jumpers' performance in a laboratory setting: a 29-year longitudinal study. J Sports Sci 2015;33:687-95.

4. Richmond SA, Kang J, Emery CA. Is body mass index a risk factor for sport injury in adolescents? J Sci Med Sport 2013;16:401-5.

5. Ozimek M, Rokowski R, Draga P, et al. The role of physique, strength and endurance in the achievements of elite climbers. PLOS One 2017;12:e0182026.

6. Lion A, van der Zwaard BC, Remillieux S, et al. Risk factors of hand climbing-related injuries. Scand J Med Sci Sports 2016;26:739-44.

7. Schlegel C, Büchler U, Kriemler S. Finger injuries of young elite rock climbers. Schweizerische Zeitschrift für 2002;50:7-10.

8. Backe S, Ericson L, Janson S, et al. Rock climbing injury rates and associated risk factors in a general climbing population. Scand $J$ Med Sci Sports 2009;19:850-6.

9. Josephsen G, Shinneman S, Tamayo-Sarver J, et al. Injuries in bouldering: a prospective study. Wilderness Environ Med 2007;18:271-80.

10. Neuhof A, Hennig FF, Schöffl I, et al. Injury risk evaluation in sport climbing. Int J Sports Med 2011;32:794-800.

11. Woollings KY, McKay CD, Emery CA. Risk factors for injury in sport climbing and bouldering: a systematic review of the literature. $\mathrm{Br} \mathrm{J}$ Sports Med 2015;49:1094-9.

12. Jones G, Asghar A, Llewellyn DJ. The epidemiology of rock-climbing injuries. Br J Sports Med 2008;42:773-8.

13. Grønhaug G, Norberg M. First overview on chronic injuries in sport climbing: proposal for a change in reporting of injuries in climbing. BMJ Open Sport Exerc Med 2016;2:e000083.

14. Grønhaug G. Self-reported chronic injuries in climbing: who gets injured when? BMJ Open Sport Exerc Med 2018;4:e000406.

15. Mehta T, Smith DL, Muhammad J, et al. Impact of weight cycling on risk of morbidity and mortality. Obes Rev 2014;15): :870-81.

16. Mogus M, Fric VO, Atalic $B$. The influence of the age, the years of training, and the BMI on the average muscle power in male and female rowers. Coll Antropol 2015;39:893-8.

17. Pons V, Riera J, Capó X, et al. Calorie restriction regime enhances physical performance of trained athletes. J Int Soc Sports Nutr 2018;15:12.

18. Taanila $\mathrm{H}$, Suni JH, Kannus $\mathrm{P}$, et al. Risk factors of acute and overuse musculoskeletal injuries among young conscripts: a populationbased cohort study. BMC Musculoskelet Disord 2015;16:104.

19. Booth FW, Roberts CK. Linking performance and chronic disease risk: indices of physical performance are surrogates for health. $\mathrm{Br} \mathrm{J}$ Sports Med 2008;42:950-2.

20. Thompson JL, Manore MM, Skinner JS, et al. Daily energy expenditure in male endurance athletes with differing energy intakes. Med Sci Sports Exerc 1995;27:347-54.

21. Degoutte $F$, Jouanel $P$, Bègue RJ, et al. Food restriction, performance, biochemical, psychological, and endocrine changes in judo athletes. Int J Sports Med 2006;27:9-18.

22. Barrack MT, Fredericson M, Tenforde AS, et al. Evidence of a cumulative effect for risk factors predicting low bone mass among male adolescent athletes. Br J Sports Med 2017;51:200-5.

23. Desaldeleer AS, Le Nen D. Bilateral fracture of the base of the middle phalanx in a climber: Literature review and a case report. Orthop Traumatol Surg Res 2016;102:409-11.

24. Thaller PH, Fürmetz J, Chen F, et al. Bowlegs and intensive football training in children and adolescents a systematic review and metaanalysis. Dtsch Arztebl Int $2018 ; 115: 401-8$. 